\title{
Keefektifan Metode Practice Rehearsal Pairs Terhadap Kemampuan Bercerita
}

\author{
${ }^{*}$ Agung Prastyo Pambudi1, Arief Budiman² \\ 1,2,3 Pendidikan Guru Sekolah Dasar, Fakultas Ilmu Pendidikan, Universitas PGRI Semarang, Indonesia
}

\author{
A R T I C L E I N F O \\ Article history: \\ Received 10 November \\ 2018 \\ Received in revised form \\ 09 December 2018 \\ Accepted 15 January 2019 \\ Available online 25 \\ February 2019 \\ Kata Kunci: \\ efektif, practice rehearsal \\ pairs, bercerita \\ Keywords: \\ efectivity, practice rehearsal \\ pairs, storytelling
}

\begin{abstract}
A B S T R A K
Penelitian ini bertujuan untuk mengidentifikasi efektif atau tidaknya metode pembelajaran Practice Rehearsal Pairs terhadap kemampuan bercerita pada siswa kelas $\mathrm{V}$ di SDN. Penelitian ini merupakan penelitian kuantitatif. Penelitian ini menggunakan One Group PretestPosttest Design. Populasi dalam penelitian ini adalah semua peserta didik kelas V di SD berjumlah 19 siswa tahun ajaran 2018/2019. Intrumen yang digunakan adalah (1) Wawancara. (2) Dokumentasi dan. (3) Tes. Analisis data menggunakan teknis analisis data uji normalitas dan uji hipotesis (uji-t). Uji normalitas digunakan untuk mengetahui kelas tersebut berdistribusi normal atau tidak. Uji hipotesis menggunakan uji t-test. Hasil penelitian yang dilakukan dapat disimpulkan bahwa metode Practice Rehearsal Pairs efektif terhadap kemampuan bercerita pada siswa kelas V di SDN Rejosari 03 Semarang. Hal ini dapat dilihat dari rata-rata hasil postest lebih tinggi dari pada pretest. Selain itu diperkuat dengan hasil perhitungan uji $t$ diperoleh thitung untuk kemampuan bercerita sebesar 18,492 dan ttabel
\end{abstract} sebesar 1,734 karena thitung $(18,492)>$ ttabel $(1,734)$ maka hal ini menunjukkan bahwa uji $t$ kemampuan bercerita signifikan.

\begin{abstract}
A B S T R A C T
This study aims to identify the effectiveness or not of the Practice Rehearsal Pairs learning method for storytelling skills in fifth grade students at SD. This research is quantitative research. This study uses one group prestest-posttest design. The population in this study were all students of grade $V$ in 19 students in the academic yar 2018/2019. The instruments used are (1) Interviews, (2) Dokumentation and 3) test. Data analysis using data analysis techniques normatility test and hypothesis testing ( $t$ test). The normality test is used to find out whether the class is normally distributed or not. Hypothesis testing uses the t-test. The results of the research conducted can be concluded that the Practice Rehearsal Pairs method is effective on the ability to tell stories to fifth grade students at SD This can be seen form the average postest results higher than the prestest. Besides that, it is reinforced by the results of t-test calculations obtained by tarithmetic for storytelling ability of 18,492 and ttable of 1,734 because tarithmetic $(18,492)>$ ttable $(1,734)$ then this indicates that the $t$ test of storytelling ability is significant.
\end{abstract}

\section{Pendahuluan}

Pendidikan merupakan padanan kata dari pedagogi (paedagogi). Pedagogi atau paedagogi berasal dari kata bahasa yunani pedagogues (paedagogia), dan dalam bahasa latin paedagogus. Pedagogues atau paedagogus, paedagogia, paedagogos, berasal dari kata paedos, paes (anak) dan agoge, ago (saya membimbing atau memimpin). Pedagogues atau paedagogus dalam kehidupan orang yunani kuno merupakan sebutan seorang yang bertugas menghantar dan menjemput anak sekolah serta mengasuhnya sebagai pembantu rumah tangga. Paedagogues itu juga berhak untuk menasehati bahkan memukul bila anak yang diasuhnya/dilayaninya nakal. Bagaimanapun, Paedagogues itu bukan guru. Dalam kehidupan

Copyright (C) Universitas Pendidikan Ganesha. All rights reserved.

Corresponding author.

E-mail addresses: Agungprastyo906@gmail.com (Agung Prastyo Pambudi) 
orang yunani kuno, guru disebut guvernor. Guru itu mengajar anak dari keluarga-keluarga secara individual, bukan klasikal.

Dari kata paedagogues, paedagogogus, paedagogia itulah kemudian muncul istilah pedagog yang berarti "pendidik", pedagogi yang berarti "perbuatan mendidik", dan paedagogiek, yang berarti "ilmu pendidikan". Pendidikan dalam bahasa inggris adalah pedagogy, yaitu: the study of educational goals and proceses (studi tentang tujuan dan proses pendidikan). Pendidik juga dapat dilacak dari kata educare yang berasal dari $e$-ducare yang artinya menggiring ke luar. Educare dapat diartikan usaha pemuliaan manusia atau pembentukan manusia (Drost dalam Soegeng, 2016).

Menurut Komar dalam Sudharto (2009: 3) dari asal dan arti kata yang terkait dengan pendidikan tersebut dapat dikelompokkan ke dalam dua ketegori, yaitu: (a) konsep pedagogic, yaitu cara untuk mempengaruhi anak agar mencapai kedewasaan (pendidikan informal), dan (b) konsep education, yaitu cara memperoleh penegtahuan di sekolah ("pendidikan formal"; pengajaran).

Menurut Susanto(2013:89) "Pembelajaran di sekolah dasar bertujuan memberikan bekal kemampuan dasar baca, tulis, hitung, pengetahuan, dan keterampilan dasar yang bermanfaat bagi siswa sesuai dengan tingkat perkembangan serta mempersiapkan mereka untuk mengikuti pembelajaran SMP".

Menurut Aunurrahman (2009:38) belajar seringkali diartikan sebagai "aktivitas untuk memperoleh pengetahuan dan berbagai kecakapan, keterampilan, dan sikap". Kemampuan orang untuk belajar menjadi ciri penting yang memebedakan jenisnya dari jenis-jenis makhluk yang lain. Dalam konteks ini sesorang dikatakan belajar bilamana terjadi perubahan, dari sebelumnya tidak mengetahui sesuatu menjadi mengetahui(Putri \& dkk, 2017).

Siswa adalah subjek yang terlibat dalam kegiatan belajar mengajar di sekolah. Dalam kegiatan tersebut siswa mengalami tindak mengajar, dan merespon dengan tindak belajar. Berkat informasi guru tentang sasaran belajar, maka siswa mengetahui apa bahan belajar baginya. Siswa mengalami suatu proses belajar. Dalam proses belajar tersebut, siswa menggunakan kemampuan mentalnya untuk mempelajari bahan ajar. Kemampuan-kemampuan pengetahuan (kognitif), sikap (afektif), keterampilan (psikomotorik) yang dibelajarkan dengan bahan belajar menjadi semakin rinci dan menguat. Adanya informasi tentang sasaran belajar, adanya penguatan-penguatan, adanya evaluasi dan keberhasilan belajar, menyebabkan siswa semakin sadar akan kemampuan dirinya (Purnawati \& dkk, 2019). Hal ini akan memperkuat keinginan untuk semakin mandiri, jadi tujuan belajar penting bagi guru dan siswa sendiri.

Mata pelajaran Bahasa Indonesia terdapat empat dasar keterampilan, yaitu keterampilan menulis, keterampilan berbicara, keterampilan membaca, dan keterampilan menyimak. Bercerita merupakan salah satu praktik kemampuan berbicara. Kegiatan bercerita adalah budaya masyarakat Indonesia sejak zaman dahulu yang mulai ditinggalkan (Izzati, 2018). Sejak zaman dahulu ibu kita mempunyai kebiasaan bercerita ketika meninabobokan anaknya ditempat tidur. Orang tua yang mahir bercerita akan disenangi anak-anaknya. Melalui bercerita dapat dijalin hubungan yang akrab. Selain itu, manfaat bercerita di antaranya yaitu (1) memberikan hiburan, (2) mengajarkan kebenaran, dan (3) memberikan keteladanan (Riana \& Spfyandanu Setiadi, 2017).

Berdasarkan obsevasi awal, yang berupa pengambilan data secara langsung di kelas V SDN Rejo sari 03 Semarang (Selasa, 02 Oktober 2018 pukul 10.00). Dengan menunjuk siswa secara bergantian untuk maju kedepan kelas untuk mempraktikan keterampilan bercerita, saya dapat mengamati bahwa siswa di dalam kelas tersebut rata-rata kemampuan berceritanya masih di bawah rata-rata. Sebelumnya saya menyiapkan satu topik yang akan di ceritakan oleh siswa, kemudian saya menyuruhnya untuk mencatatnya di buku mereka. Siswa hanya mampu bercerita beberapa paragraf saja, dan ceritanya kurang sesuai dengan apa yang dituliskan di bukunya. Berdasarkan pengamatan saya, salah satu penyebab dari rendahnya kemampuan bercerita adalah kurang terasahnya kemampuan siswa dalam bercerita, dan tidak adanya variasi dalam mengajarkan kemampuan bercerita yang dilakukan oleh guru. Sehingga siswa masih terlihat gugup ketika maju bercerita. Hal itu dapat dibuktikan dengan hasil pengamatan di dalam kelas sebagai berikut:

Tabel 1. Data Awal

\begin{tabular}{ccccc}
\hline No. & Kriteria Ketuntasan Minimal & Jumlah & Presentasi & Keterangan \\
\hline 1. & $\leq 70$ & 13 & $68 \%$ & Tidak Tuntas \\
2. & $\geq 70$ & 6 & $32 \%$ & Tuntas \\
\hline
\end{tabular}

Pembelajaran yang demikian ini sudah saatnya untuk di tingkatkan. Peserta didik haruslah lebih aktif dalam pembelajaran. Agar tujuan pembelajaran tercapai, maka guru perlu memilih metode pembelajaran yang tepat. Pada saat ini banyak dikembangkan metode-metode pembelajaran. Metode-metode pembelajaran tersebut sangat bergantung pada tujuan yang akan dicapai oleh guru. Metode pembelajaran 
tersebut diantaranya adalah metode pembelajaran Practice Rehearsal Pairs dan masih banyak lagi metode pembelajaran yang lain.

Metode Practice Rehearsal Pairs termasuk ke dalam model pembelajaran aktif. Pembelajaran aktif merupakan langkah cepat, menyenangkan, menarik, dan mencerdaskan dalam belajar. Practice Rehearsal Pairs adalah metode sederhana yang dapat dipakai untuk mempraktikkan suatu keterampilan atau prosedur dengan patner belajar. Tujuannya adalah untuk meyakinkan bahwa kedua patner dapat melaksanakan kecakapan atau prosedur. Materi yang bersifat psikomotorik sangatlah tepat untuk metode ini. Dalam hal ini peserta didik dituntut untuk melaksanakan keterampilan bercerita dengan benar dan lancar (Hamruni, 2012).Berdasarkan latar belakang, maka judul yang dipilih dalam penelitian ini adalah "Keefektifan Metode Practice Rehearsal Pairs terhadap Kemampuan Bercerita Pada Siswa Kelas V di SDN Rejosari 03 Semarang". Berdasarkan latar belakang masalah, maka dapat diidentifikasi sebagai berikut: 1) Keterampilan siswa masih rendah pada materi kemampuan bercerita karena kurang terasahnya kemampuan bercerita siswa, 2) Guru jarang melatih kemampuan bercerita siswa, 3) Guru hanya memberikan perintah langsung kepada siswa untuk bercerita tanpa menggunakan metode saat pembelajaran, 4) Kemampuan siswa dalam bercerita masih dibawah kriteria nilai KKM.

Berdasarkan latar belakang dan identifikasi masalah diatas maka yang dibatasi dalam penelitian ini adalah : 1) Penelitian terbatas pada metode pembelajaran Practice Rehearsal Pairs, 2) Sasaran penelitian terbatas pada kemampuan siswa. Berdasarkan Identifikasi masalah dan pembatasan masalah di atas, maka dapat dirumuskan masalah sebagai berikut: Apakah metode Practice Rehearsal Pairs efektif terhadap kemampuan bercerita pada siswa kelas V di SDN Rejosari 03 Semarang?. Berdasarkan rumussan masalah, diperoleh tujuan penelitian sebagai berikut : Untuk mengetahui keefektifan penggunaan metode Practice Rehearsal Pairs terhadap kemampuan bercerita pasa siswa kelas V di SDN Rejosari 03 Semarang.

\section{Metode}

Penelitian ini merupakan penelitian kuantitatif. Penelitian ini menggunakan One Group PretestPosttest Design. Penelitian dilaksanakan di SDN Rejosari 03 Semarang pada tanggal 10, 11, dan 12 Desember 2018 pada tahun ajaran 2018/2019 semester ganjil pada siswa kelas V SDN Rejosari 03 Semarang Tahun pelajaran 2018/2019. Populasi dalam penelitian ini adalah seluruh peserta didik kelas V SDN Rejosari 03 Semarang berjumlah 19 siswa tahun ajaran 2018/2019. Bentuk desain eksperimen yang digunakan yaitu Pre-Experimental Designs (Nondesigns). Bentuk Pre eksperimental Desain yang digunakan adalah One-Group Pretest-Posttest Design. Dengan demikian hasil perlakuan dapat diketahui lebih akurat, karena dapat membandingkan dengan keadaan yang sebelum diberi perlakuan. Desain ini dapat digambarkan sebagai berikut:

Teknik pengumpulan data dalam penelitian ini adalah wawancara, dokumentasi dan tes. Wawancara bertujuan untuk mendapatkan informasi tentang kondisi awal siswa serta materi yang akan diajarkan. Dokumentasi dalam penelitian ini digunakan untuk mendapatkan dokumen sekolah mengenai nama siswa, jumlah siswa, dan data-data yang diperlukan dalam penelitian. Metode dokumentasi digunakan untuk daftar nilai, daftar nama siswa dan dokumen pelaksanaan kegiatan pembelajaran selama penelitian.

Teknik tes digunakan untuk menilai kemampuan siswa yang mencakup pengetahuan dan keterampilan hasil belajar, bakat dan intelegasi yang dimiliki siswa. Penulis melakukan tes untuk mengetahui hasil belajar keterampilan dengan memberikan soal kepada siswa. Instrumen soal yang diberikan kepada siswa telah divalidasi oleh dosen ahli. Soal yang diberikan adalah petunjuk soal yang didalamnya berupa kalimat perintah untuk menyusun sebuah cerita pada praktik kemampuan bercerita, tes berupa pretest dan post tes. Penganalisaan hasil yaitu menganalisa item soal yang diuji cobakan melalui validasi instrumen oleh dosen ahli, yaitu Ibu Ikha Listiarini, S.Pd.,M.Hum dan Ibu Anggun Dwi Setya Putri S.Pd.,M.Pd. Setelah melakukan validasi instrumen oleh dosen ahli kemudian dilanjutkan melakukan penelitian di kelas V SDN Rejosari 03 Semarang.

Teknik analisis dalam penelitian ini ada beberapa tahapan, yaitu tahap awal yang merupakan tahap pemadaman sampel dan tahap akhir yang merupakan tahap analisis data untuk menguji hipotesis penelitian.

\section{Uji Normalitas Awal (Pretest)}

Uji normalitas dilakukan untuk mengetahui populasi berdistribusi normal atau tidak. Hipotesis sebagai berikut:

$\mathrm{H}_{0}$ : data berdistribusi normal

$\mathrm{H}_{1}$ : data tidak berdistribusi normal 
Sudjana (2005:466-467) uji kehormatan dilakukan secara parametrik dengan menggunakan penaksir rata-rata dan simpangan baku, maka dalam bagian ini akan diperhatikan uji kenormalan secara non parametrik. Uji yang digunakan dikenal dengan uji Liliefors. Misal sampel acak dengan hasil pengamatan $\mathrm{x}_{1}, \mathrm{x}_{2}, . . \mathrm{x}_{\alpha}$. Sampel uji hipotesis nol bahwa sampel berasal dari populasi berdistribusi normal melawan hipotesis tandingan bahwa berdistribusi tidak normal.

\section{Uji Normalitas Akhir (Posttest)}

Langkah-langkah pengujian normalitas sama dengan langkah-langkah uji normalitas pada analisis data awal. Menurut Sudjana (2005) uji kenormalan dilakukan secara parametrik dengan menggunakan penaksir rata-rata dan simpangan baku, maka dalam bagian ini akan diperhatikan uji kenormalan secara nonparametrik. Uji yang digunakan dikenal dengan uji Liliefors. Misal sampel acak dengan hasil pengamatan $\mathrm{x}_{1}, \mathrm{x}_{2}, \ldots \mathrm{Z}_{\mathrm{n}}$, sampel uji hipotesis nol bahwa sampel berasal dari populasi berdistribusi normal melawan hipotesis tandingan bahwa berdistribusi tidak normal.

\section{Uji T-test}

Cara mengetahui adakah perbedaan hasil belajar siswa, maka digunakan $U j i-t$ adapun rumus yang digunakan yaitu:

$$
T=\frac{\text { Md }}{\sqrt{\frac{\sum X^{2} d}{N(N-1)}}}
$$

Keterangan:

Md : Mean dari deviasi (d) antara Pretest dan Posttest

$\sum$ : Jumlah kuadrat deviasi

$\mathrm{Xd}$ : Deviasi masing-masing subjek (d-Md)

$\mathrm{N}$ : Banyaknya subjek pada sampel

$\mathrm{db}$ : Ditentukan dengan $(\mathrm{N}-1)$

Uji t-test digunakan untuk mengetahui perbedaan antara hasil belajar siswa sebelum diberi perlakuan dan sesudah diberi perlakuan.

\section{Hasil dan Pembahasan}

Hasil penelitian yang telah dilaksanakan yaitu "Keefektifan Metode Practice Rehearsal Pairs Terhadap Kemampuan Bercerita Pada Siswa Kelas V SDN Rejosari 03 Semarang”. Penelitian ini dilaksanakan pada tanggal 10, 11, 12 Desember 2018. Pada Kriteria Ketuntasan Minimal (KKM) kemampuan bercerita 70. Dalam penelitian ini menggunakan satu kelas dengan jumlah 19 siswa. Penelitian ini merupakan penelitian kuantitatif yang menggunakan validasi uji instrumen. Penelitian ini menggunakan desain ekperimen dengan jenis One Group Pretest Posttest Design. Dalam design ini terdapat pretest sebelum diberi perlakuan untuk mengetahui keadaan awal dan posttest untuk mengetahui keefektifan metode Practice Rehearsal Pairs terhadap kemampuan bercerita pada siswa.

Penelitian ini merupakan penelitian untuk mengetahui keefektifan metode Practice Rehearsal Pairs terhadap kemampuan bercerita pada siswa kelas V. Penelitian ini diawali dengan membuat soal untuk kemampuan bercerita sesuai dengan materi yang telah ditentukan dengan jumlah 2 petunjuk soal untuk kemampuan bercerita. Petunjuk soal kemampuan bercerita tersebut divalidasikan kepada dosen Universitas PGRI Semarang. Dari petunjuk soal kemampuan bercerita yang telah divalidasikan terdapat beberapa kalimat yang harus direvisi. Selanjutnya petunjuk soal kemampuan bercerita tersebut telah dapat digunakan untuk penelitian. Jumlah 2 petunjuk soal kemampuan bercerita telah lolos validasi, selanjutnya petunjuk soal bercerita tersebut digunakan penelitian untuk pretest dan posttest. Data hasil penelitian diperoleh dari nilai pretest dan posttest hasil belajar siswa. Nilai pretest dan posttest dinyatakan tuntas jika memenuhi nilai KKM. Adapun Kriteria Ketuntasan Maksimal (KKM) kemampuan bercerita di SD N Rejosari 03 Semarang yaitu 70. Perhitungan nilai pretest dan nilai posttest setelah diberikan perlakuan hasilnya berbeda. Berikut tabel nilai pretest dan posttest siswa kelas V SDN Rejosari 03 Semarang.

Data hasil belajar nilai pretest dan posttest siswa kelas V SDN Rejosari 03 Semarang tahun ajaran 2018/2019 dapat dilihat pada Tabel 1:

Tabel 2. Data Hasil pretest dan posttest

\begin{tabular}{lcc}
\hline Keterangan & Pretest & Posttest \\
\hline Nilai tertinggi & 75 & 95 \\
Nilai terendah & 25 & 65 \\
\hline
\end{tabular}




\begin{tabular}{lcc}
\hline Rata-rata & 53,95 & 80,00 \\
Siswa tuntas & 5 & 18 \\
Siswa tidak tuntas & 14 & 1 \\
\hline
\end{tabular}

Sumber: Olah Data (2018)

Berdasarkan Tabel 1 terdapat perbedaan antara nilai terendah, nilai tertinggi, nilai rata-rata kelas dan jumlah siswa yang tuntas dan tidak tuntas pada saat pretest dan posttest. Nilai pretest diperoleh nilai terendah 25, nilai tertinggi 75 sedangkan nilai posttest diperoleh nilai terendah 65 dan nilai tertinggi 95 dengan nilai rata-rata pretest 53,95 dan rata nilai posttest 80,00. Selain dalam bentuk tabel, data analisis hasil belajar dapat dilihar pada diagram pada Gambar 2:

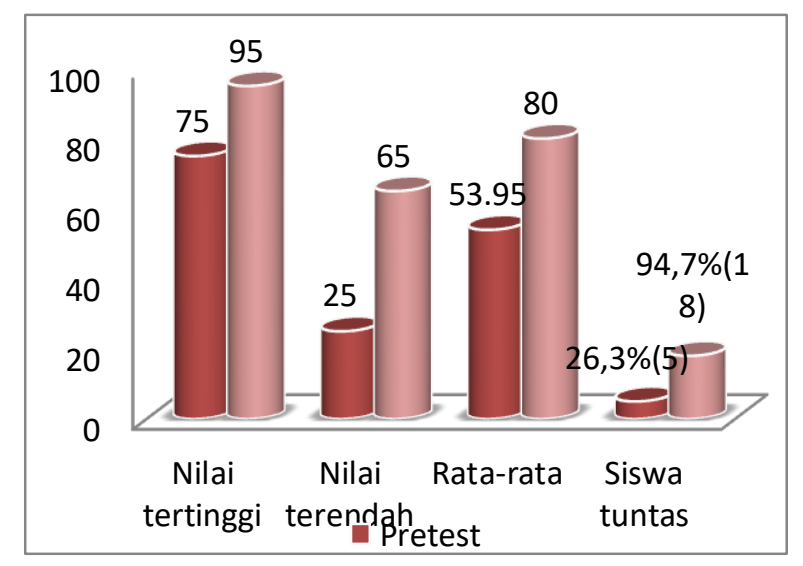

Gambar 2. Diagram Hasil Pretest dan Posttest

Analisis data dilakukan untuk menguji hipotesis sehingga dapat diambil suatu keputusan kesimpulan dari penelitian yang telah dilakukan. Sebelum melakukan uji hipotesis, data hasil penelitian dilakukan uji normalitas terlebih dahulu. Persyaratan data dilakukan untuk pengujian data hasil belajar dengan menggunakan uji liliefors pada taraf signifikan sebesar 5\%. Perhitungan uji normalitas digunakan untuk mengetahui hasil pretest dan posttest berdistribusi normal atau tidak.

1. Uji Normalitas Data Awal (Pretest)

Analisis data awal dilakukan untuk mengkaji apakah sampel berasal dari data berdistribusi normal atau tidak. Uji normalitas data awal pada penelitian ini menggunakan data pretest. Pengujian normalitas menggunakan uji liliefors pada taraf signifikan sebesar 5\%, dengan kriteria sebagai berikut:

$\mathrm{H}_{\mathrm{o}}$ : Maka sampel berasal dari populasi yang berdistribusi normal.

$\mathrm{H}_{\mathrm{a}}$ : Maka sampel berasal dari populasi yang berdistribusi tidak normal.

Dengan kriteria penemuan hipotesis $\mathrm{H}_{0}$ jika $\mathrm{L}_{0}<\mathrm{L}_{\text {tabel. }}$

Dari hasil perhitungan menggunakan uji liliefors dapat dilihat pada tabel berikut:

Tabel 3. Hasil Uji Normalitas Data Awal (Pretest)

\begin{tabular}{ll}
\hline Data & Pretest \\
\hline $\mathrm{L}_{0}$ & 0,1892 \\
$\mathrm{~L}_{\text {tabel }}$ & 0,195 \\
Kriteria & Berdistribusi Normal \\
\hline
\end{tabular}

Sumber: Olah Data, 2018

Berdasarkan Tabel 4.3 dapat dijelaskan bahwa diperoleh nilai $\mathrm{L}_{0}=0,1892$ dengan taraf signifikan 5\% $\mathrm{n}=19$ maka diperoleh $\mathrm{L}_{\text {tabel }}=0,195$. Karena $\mathrm{L}_{0}<\mathrm{L}_{\text {tabel }}$ maka artinya data berdistribusi normal. Jadi data nilai pretest menunjukkan bahwa sampel berasal dari populasi berdistribusi normal.

\section{Uji Normalitas Data Akhir (Posttest)}

Data akhir diperoleh dari nilai posttest siswa kelas V SDN Rejosari 03 Semarang. Data berasal dari soal posttest yang terdiri dari 1 petinjuk soal untuk bercerita. Untuk mengetahui data ini perlu dilakukan uji normalitas data. 
Uji normalitas dilakukan dengan tujuan untuk mengetahui apakah sampel berasal dari populasi yang berdistribusi normal atau tidak. Pengujian normalitas menggunakan uji liliefors, pada taraf signifikan sebesar 5\% dengan kriteria sebagai berikut:

$\mathrm{H}_{\mathrm{o}}$ : Maka sampel berasal dari populasi yang berdistribusi normal.

$\mathrm{H}_{\mathrm{a}}$ : Maka sampel berasal dari populasi yang berdistribusi tidak normal.

Dengan kriteria penemuan hipotesis $\mathrm{H}_{0}$ jika $\mathrm{L}_{0}<\mathrm{L}_{\text {tabel. }}$

Data hasil perhitungan menggunakan uji liliefors dapat dilihat pada Tabel 3 berikut:

Tabel 4. Hasil Uji Normalitas Data Nilai Posttest

\begin{tabular}{ll}
\hline Data & Posttest \\
\hline $\mathrm{L}_{0}$ & 0,1894 \\
$\mathrm{~L}_{\text {tabel }}$ & 0,195 \\
Kriteria & Berdistribusi Normal \\
\hline
\end{tabular}

Sumber: Olah Data, 2018

Berdasarkan hasil pengujian normalitas data posttest diperoleh nilai $\mathrm{L}_{0}=0,1894$ dengan taraf signifikan $5 \% \mathrm{n}=19$ maka diperoleh $\mathrm{L}_{\text {tabel }}=0,195$. Karena $\mathrm{L}_{0}<\mathrm{L}_{\text {tabel }}$ maka artinya data berdistribusi normal. Jadi data nilai posttest menunjukkan bahwa sampel berasal dari populasi berdistribusi normal.

3. Uji t Satu Sampel

Pengujian hipotesis menggunakan uji t satu sampel. Uji t satu sampel merupakan salah satu uji parametrik. Biasanya digunakan untuk ukuran sampel dibawah 30. Syaratnya adalah data berupa kuantitaif dan memiliki distribusi normal. Pengujian satu sampel pada prinsipnya dilakukan untuk menguji perbedaan rata-rata pretest dan posttest. Hipotesis yang akan diuji:

$\mathrm{H}_{0}$ : Jika $\mathrm{t}_{\text {hitung }} \leq \mathrm{t}_{\text {tabel }}$ maka $\mathrm{H}_{0}$ diterima atau dapat dikatakan bahwa metode Practice Rehearsal Pairs tidak efektif terhadap kemampuan bercerita pada siswa kelas V di SDN Rejosari 03 Semarang.

$\mathrm{H}_{\mathrm{a}}$ : Jika $t_{\text {hitung }} \geq \mathrm{t}_{\text {tabel }}$ maka $\mathrm{H}_{\mathrm{a}}$ diterima atau dapat dikatakan bahwa metode Practice Rehearsal Pairs sangat efektif terhadap kemampuan bercerita pada siswa kelas V di SDN Rejosari 03 Semarang.

Rumus uji t yang digunakan adalah sebagai berikut:

$$
t=\frac{\mathrm{Md}}{\sqrt{\frac{\sum X^{2} d}{N(N-1)}}}
$$

Keterangan :

Md : Mean dari deviasi (d) antara Pretest dan Posttest

$\sum \mathrm{X}^{2} \quad$ : Jumlah kuadrat deviasi

$\mathrm{Xd} \quad$ : Deviasi masing-masing subjek (d-Md)

$\mathrm{N} \quad$ : Banyaknya subjek pada sampel

db : Ditentukan dengan (N-1)

Berdasarkan uji t pada lampiran diperoleh data sebagai berikut:

Tabel 5. Hasil Perhitungan Uji t

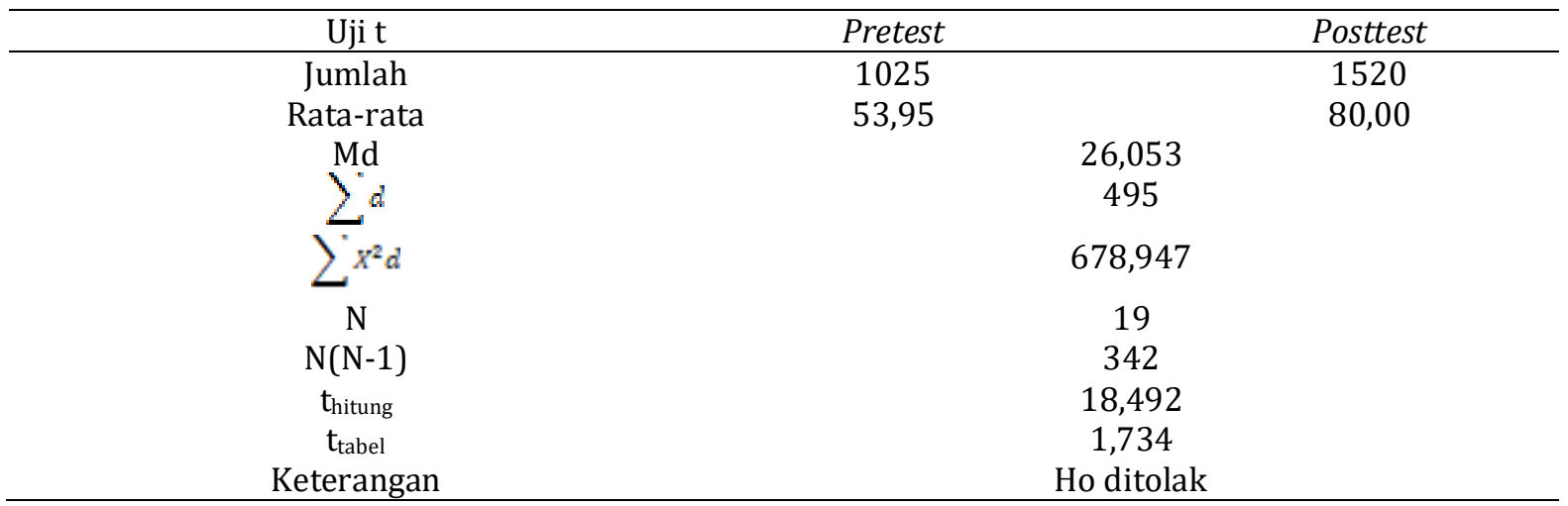


Berdasarkan Tabel 4.5 diperoleh harga $t_{\text {hitung }}=18,492$. Selanjutnya harga $t_{\text {hitung tersebut }}$ dibandingkan dengan $t_{\text {tabel }}=1,734$ dengan $\mathrm{db}=20-1$ pada taraf signifikan $5 \%$, sehingga diperoleh harga $t_{\text {hitung }}>t_{\text {tabel }}$ yaitu 18,492 $>1,734$. Dengan demikian Ho ditolak dan Ha diterima. Dapat disimpulkan bahwa metode Practice Rehearsal Pairs efektif terhadap kemampuan bercerita pada siswa kelas V di SDN Rejosari 03 Semarang.

Berdasarkan hasil penelitian, didapatkan Pembahasan sebagai berikut:

\section{Hasil Belajar}

Berdasarkan penelitian yang sudah dilakukan hasil tes pretest menunjukkan bahwa dari 19 siswa hanya 5 anak yang mencapai nilai KKM. Nilai KKM pada mata pelajaran Bahasa Indonesia yaitu 70. Nilai terendah 25, nilai tertinggi 75 Dengan rata-rata nilai pretest 53,95. Sedangkan hasil posttest menunjukkan bahwa dari 19 siswa hanya 1 siswa yang tidak tuntas. Nilai terendah 65, nilai tertinggi 95 dengan rata-rata nilai 80,00. Hal ini menunjukkan adanya perbedaan antara hasil belajar sebelum menggunakan metode Practice Rehearsal Pairs dan hasil belajar setelah menggunakan dengan metode Practice Rehearsal Pairs. Sedangkan untuk hasil afektif siswa, dalam pembelajaran ini dinilai pada saat pembelajaran menggunakan metode Practice Rehearsal Pairs.

Analisis data pada penelitian terdiri dari data awal dan data akhir. Berdasarkan hasil analisis data awal ini diketahui bahwa data berdistribusi normal dengan nilai $\mathrm{L}_{0}=0,1892$ dengan taraf signifikan $5 \% \mathrm{n}$ = 19 maka diperoleh $\mathrm{L}_{\text {tabel }}=0,195$. Sedangkan hasil analisis data akhir yang telah dilakukan dengan uji normalitas menunjukkan bahwa sampel berasal dari populasi yang berdistribusi normal dengan $\mathrm{L}_{0}=$ 0,1894 dengan taraf signifikan $5 \% \mathrm{n}=19$ maka diperoleh $\mathrm{L}_{\text {tabel }}=0,195$.

Hasil hipotesis menggunakan uji $\mathrm{t}$ membuktikan bahwa terdapat keefektifan metode Practice Rehearsal Pairs terhadap kemampuan bercerita pada siswa kelas V di SDN Rejosari 03 Semarang. Berdasarkan perhitungan uji $t$ dari hasil belajar diperoleh $t_{\text {hitung }}=18,492$ dan $t_{\text {tabel }}=1,734$. Karena $t_{\text {hitung }}>$ $t_{\text {tabel }}$ maka $\mathrm{H}_{0}$ ditolak dan $\mathrm{H}_{\mathrm{a}}$ diterima.

\section{Keterampilan}

Usman dan Setiawati dalam Susanto (2013: 9) mengemukakan bahwa keterampilan proses merupakan keterampilan yang mengarah kepada pembangunan kemampuan mental, fisik, dan sosial yang mendasar sebagai penggerak kemampuan yang lebih tinggi dalam diri individu siswa. Keterampilan berarti kemampuan menggunakan pikiran, nalar, dan perbuatan secara efektif dan efisien untuk mencapai suatu hasil tertentu, termasuk kreativitasnya. Dalam melatih keterampilan proses, secara bersamaan dikembangkan pula sikap-sikap yang dikehendaki, seperti kreativitas, kerja sama, bertanggung jawab, dan berdisiplin sesuai dengan penekanan bidang studi yang bersangkutan (Agustini \& Syarifuddin, 2015). Dalam penelitian ini yang dinilai adalah keterampilan bercerita siswa saat pembelajaran sebelum dan sesudah menggunakan metode Practice Rehearsal Pairs.

\section{Sikap}

Untuk hasil afektif siswa, dalam pembelajaran ini dinilai pada saat pembelajaran menggunakan metode Practice Rehearsal Pairs. Hasil penilaian afektif yang dinilai adalah sikap percaya diri, kreativitas, bertanggung jawab. Indikator penilaian dari aspek sikap percaya diri yaitu siswa mampu bercerita dengan percaya diri, siswa mampu mengemukakan masalah dengan benar, indikator aspek sikap kreativitas yaitu siswa mampu membuat cerita pendek dengan menarik, indikator aspek sikap bertanggung jawab yaitu siswa mampu bertanggung jawab dengan menyelesaikan cerita pendek secara tepat. Masing-masing indikator skor maksimal 4 dengan kriteria baik sekali. Nilai afektif dilakukan saat proses pembelajaran menggunakan metode Practice Rehearsal Pairs, diperoleh rata-rata nilai afektif tiap asepek sikap. Pada aspek sikap percaya diri dari masing-masing pertemuan diperoleh nilai rata-rata 98,02, aspek sikap kreativitas dperoleh rata-rata 82,89, aspek sikap bertanggung jawab diperoleh rata-rata 78,28. Sesuai dengan penelitian yang saya lakukan dengan menggunakan metode Practice Rehearsal Pairs siswa mampu menampilkan kemampuan bercerita secara individu, sehingga dari kemampuan tersebut dapat meningkatkan percaya diri siswa, kreativitas, dan bertanggung jawab.

\section{Kelebihan Metode Practice Rehearsal Pairs}

Sesuai dengan keunggulan metode Practice Rehearsal Pairs (praktik berpasangan) dimana disebutkan (Hamruni, 2009) metode Practice Rehearsal Pairs merupakan salah satu strategi yang berasal dari pembelajaran aktif. Pembelajaran aktif adalah suatu pembelajaran yang mengajak siswa untuk belajar secara aktif. Belajar aktif merupakan langkah cepat, menyenangkan, menarik, dan mencerdaskan 
dalam belajar. Dalam pembelajaran model ini, para siswa tidak hanya terpaku di tempat-tempat duduk mereka, tapi berpindah-pindah, bekolaborasi, dan berpikir keras (Hamruni, dalamManullang, 2017). Belajar secara aktif membantu siswa dalam meningkatkan teknik dan kemampuan mendengar, mengamati, mengajukan pertanyaan, dan mendiskusikan materi pelajaran yang dipelajari dengan siswa lain. Hal yang sangat dalam aktivitas belajar aktif adalah para siswalah yang melakukan kegiatan belajar, merekalah yang harus mencari dan memecahkan masalah sendiri, menemukan contoh-contoh, mencoba keterampilan-keterampilan, dan melakukan tugas-tugas pembelajaran yang harus dicapai.

Metode Practice Rehearsal Pairs yaitu metode dimana siswa dikelompokkan dalam pasangpasangan (berpasangan) dengan temannya sendiriyang satu mengamati dan yang satunya lagi mempraktikkan. Metode ini adalah metode sederhana yang dapat digunakan untuk mempraktikkan suatu keterampilan atau prosedur dengan teman belajar serta latihan praktik berulang-ulang menggunakan informasi untuk mempelajarinya (Hamruni, 2009:289).

Pembelajaran dalam metode ini dikembangkan praktik dan komunikasi dengan tujuan agar peserta didik saling berbagi kemampuan, saling belajar berfikir kritis, saling menyampaikan pendapat, saling memberi kesempatan menyalurkan kemampuan, saling membantu belajar, saling menilai kemampuan dan peranan diri sendiri maupun teman lain (Widianingsih, 2017). Tujuannya adalah untuk melibatkan peserta didik aktif sejak dimulainya pembelajaran, yakni untuk meyakinkan dan memastikan bahwa kedua pasangan dapat memperagakan prosedur atau keterampilan dengan benar, selain itu juga dengan praktik berpasangan dapat meningkatkan keakraban dengan siswa dan untuk memudahkan dalam mempelajari materi yang bersifat psikomotor.

\section{Keterkaitan Dengan Teori Belajar}

Berdasarkan teori belajar dari Piaget, berpendapat bahwa perkembangan proses belajar pada anak dipengaruhi oleh struktur dan perkembangan mental pada setiap anak. Dari data hasil penelitian menggunakan metode Practice Rehearsal Pais, metode tersebut dapat meningkatkan struktur dan perkembengan mental pada diri anak. Dalam metode ini, sebelum melakukan kegiatan bercerita, siswa belatih dahulu secara berulang-ulang dengan pasangannya sampai keterampilan tercapai. Sehingga hal tersebut dapat meningkatkan perkembangan mental anak. Dalam teori belajar dari R. Gagne, berpendapat bahwa belajar adalah suatu proses untuk memperoleh motivasi dan penguasaan pengetahuan atau keterampilan yang diperoleh dari instruksi. Keterkaitan dengan metode Practice Rehersal Pairs yang saya gunakan saat pembelajaran yaitu dalam pembelajan ini siswa akan memperoleh motivasi melalui kegiatan bercerita, karena sebelum praktik kemampuan bercerita siswa berlatih secara berpasangan sehingga akan menimbulkan rasa semangat dalam diri siswa. Selanjutnya melalui instruksi yang diberikan oleh guru yang sesuai dengan langkah-langkah metode practice rehearsal pairs maka siswa akan memperoleh keterampilan dalam bercerita.

\section{Keterkaitan Dengan Penelitian Yang Relevan}

Penelitian ini memliki keterkaitan dengan penelitian sebelumnya yang dilakukan oleh Rahmat Sujiyanto (2016), Lestari (2014), dan Fatkhullah (2011). Keterkaitannya yaitu sama-sama menggunakan metode Practice Rehearsal Pairs dalam pembelajaran. Jika dilihat dari hasil pembelajaran juga memiliki keterkaitan yaitu sama-sama dapat meningkatkan hasil belajar. Terbukti dengan hasil penelitian yang saya lakukan yaitu kemampuan bercerita siswa meningkat setelah diterapkan metode Practice Rehearsal Pairs.

\section{Nilai Karakter Yang Muncul}

Berdasarkan penelitian dengan menggunakan metode Practice Rehearsal Pairs terdapat 2 nilai karakter yang muncul pada saat pembelajaran berlangsung, yaitu karakter kreatif dan bertanggung jawab. Kreatifitas siswa muncul pada saat membuat cerita pendek yang dihubungkan dengan tema ekosistem, sehingga hasil cerita yang dibuat oleh siswa menjadi menarik. Sedangkan nilai karakter bertanggung jawab muncul pada saat siswa maju bergantian untuk bercerita. Meskipun siswa merasa malu saat ingin maju kedepan untuk bercerita, tetapi mereka tetap memberanikan diri untuk maju kedepan untuk bercerita karena mereka bertanggung jawab terhadap tugas yang telah diberikan oleh peneliti.

\section{Simpulan dan Saran}

Berdasarkan hasil penelitian dan pembahasan, maka dapat disimpulkan bahwa ada peningkatan kemampuan bercerita siswa dengan menggunakan metode Practice Rehearsal Pairs. Metode Practice Rehearsal Pairs efektif terhadap kemampuan bercerita siswa yang dibuktikan dengan peningkatan kemampuan bercerita sebelum dan sesudah diberi perlakuan. Sebelum diberi perlakuan rata-rata 
kemampuan bercerita siswa 53,95 sedangkan setelah diberi perlakuan rata-rata nilai kemampuan bercerita siswa 80,00. Berdasarkan perhitungan uji t dari kemampuan bercerita diperoleh thitung $=$ 18,492 dan ttabel=1,734. Karena thitung $>$ ttabel maka H0 ditolak dan Ha diterima. Berdasarkan data yang diperoleh dari penelitian dapat disimpulkan bahwa metode Practice Rehearsal Pairs efektif terhadap kemampuan bercerita.

Berdasarkan simpulan setelah melakukan penelitian ini, maka peneliti memberikan saran sebagai berikut: 1. Guru diharapkan menggunakan metode pembelajaran yang tepat, seperti metode Practice Rehearsal Pairs yang dapat meningkatkan hasil belajar siswa, 2. Berdasarkan penelitian yang dilaksanakan, saat pembelajaran berlangsung guru harus selalu memantau dan memperhatikan siswa saat melaksanakan prosedur, 3. Guru diharapkan lebih memperhatikan kegiatan siswa agar tahu bagaimana siswa melakukan prosedur sesuai langkah-langkah metode Practice Rehearsal Pairs yang digunakan, dengan harapan dapat meningkatkan keaktifan siswa melalui praktek yang dapat membantu siswa dalam pemahaman suatu keterampilan sehingga hasil belajar siswa meningkat

\section{Daftar Rujukan}

Agustini, Y., \& Syarifuddin, A. (2015). Penerapan Model Student Teams Achievement Division (Stad) Dalam Meningkatkan Hasil Belajar Siswa Kelas V Pada Mata Pelajaran Ipadi Mi Qur'aniah IV Palembang. Jurnal Radenfatah, 2(1), 197-222.

Aunurrahman. (2009). Belajar dan Pembelajaran. Bandung. Bandung: Alfabeta.

Fatkhullah, M. (2011). Keefektifan Strategi Pembelajaran Practice Rehearsal Pair Dengan Alat Peraga Simetri Lipat dan Simetri Putar Dalam Meningkatkan Hasil Belajar Peserta Didik Kelas VII MTs NU 05 Sunan Katong Kaliwungu Tahun Pelajaran 2010/2011. , Universitas Islam Negeri Walisongo Semarang.

Hamruni. (2009). Strategi dan Model-Model Pembelajaran Aktif, Menyenangkan. Yogjakarta: : Fakultas UIN Sunan Klijaga.

Hamruni. (2012). Strategi Pelajaran. Yogjakarta: Insan Mandani.

Izzati, I. Q. N. (2018). Ketrampilan Berbicara dalam Teks Narasi Imajinasi. Surakarta: Universitas Sebelas Maret.

Lestari, I. P. (2014). fektivitas Practice Rehearsal Pairs dan Media Audio Visual Terhadap Hasil Belajar Materi Pokok Hafalan Surat Al-'Adiyat Peserta Didik Kelas IV MI Miftahul Akhlaqiyah BeringinNgaliyan. Universitas Islam Negeri Walisongo.

Manullang, F. R. (2017). Peningkatan Hasil Belajar IPS Dengan Menggunakan Strategi Pembelajaran Aktif Team Quiz Siswa Kelas V SDN 42 Palembang. Wahana Didaktika. Wahana Didaktika, 15(1), 38-51.

Purnawati, L., \& dkk. (2019). Pengaruh Model Pembelajaran Inkuiri Terbimbing Terhadap Hasil Belajar Siswa Pada Materi Macam-Macam Gaya. Journal for Lesson and Learning Studies, 2(1), 64-72.

Putri, S. S. I., \& dkk. (2017). Penerapan Metode Pembelajaran Demonstrasi Di Sanggar Lintang Art Kediri. Jurnal Pendidikan Seni Rupa, 17(2), 292-299.

Riana, W., \& Spfyandanu Setiadi. (2017). Pelajaran Bahasa Indonesia Peserta Didik Kelas XI SMK Garuda Nusantara. Jurnal Dinamika Sosbud, 17(2), 292-299.

Soegeng. (2016). Konsep Pendidikan Dan Pengajaran Rangkuman Telaah Kritis Perbedaan, Hubungan, dan Penerapannya. Semarang: Prosiding Seminar Nasional \& Bedah Buku, Universitas PGRI Semarang.

Sudjana. (2005). Metode Statistika. Bandung: Tarsito Bandung.

Sujiyanto, R. (2016). Penerapan Strategi Practice Rehearsal Pairs dalam Peningkatan Pembelajaran IPA Kelas V SDN Kalijaran 01 Maos Cilacap. Kalam Cendekia PGSD Kebumen, 4(2). 
Susanto, A. (2013). Teori Belajar dan Pembelajaran di Sekolah Dasar. Jakarta: Kencana Predana Media Group.

Widianingsih, C. (2017). Pengaruh Penerapan Model Kooperatif Tipe Stad Terhadap Kemampuan Mengapresiasi Cerita Anak Di Kelas V Sekolah Dasar Negeri Kramat III Kecamatan Kejaksan Kota Cirebon. E-Jurnal Literasi Unswagati Cirebon, 1(1), 43-52. 